\title{
The role of toll-like receptors in acute and chronic lung inflammation
}

Erin I Lafferty ${ }^{1}$, Salman T Qureshi ${ }^{1,2^{*}}$, Markus Schnare ${ }^{3^{*}}$

\begin{abstract}
By virtue of its direct contact with the environment, the lung is constantly challenged by infectious and non-infectious stimuli that necessitate a robust yet highly controlled host response coordinated by the innate and adaptive arms of the immune system. Mammalian Toll-like receptors (TLRs) function as crucial sentinels of microbial and non-infectious antigens throughout the respiratory tract and mediate host innate immunity. Selective induction of inflammatory responses to harmful environmental exposures and tolerance to innocuous antigens are required to maintain tissue homeostasis and integrity. Conversely, dysregulated innate immune responses manifest as sustained and self-perpetuating tissue damage rather than controlled tissue repair. In this article we review aspects of Toll-like receptor function that are relevant to the development of acute lung injury and chronic obstructive lung diseases as well as resistance to frequently associated microbial infections.
\end{abstract}

\section{Introduction}

As an essential interface between the environment and the internal milieu, the lungs are continuously exposed to dust, pollen, chemicals, and microbial pathogens. Pneumonia and related patterns of lower respiratory tract infection are a frequent consequence of this interaction and account for a significant proportion of human morbidity and mortality throughout the world [1,2]. To contain potential environmental threats, the lungs are equipped with complex and multifaceted host defences. During tidal ventilation, the complex geometry of the nasal passages and branching pattern of the central airways impede the penetration of relatively large or heavy infectious particles while tight intercellular junctions ensure the structural integrity of the lung epithelium. This barrier is enhanced by airway goblet cells that secrete mucus and ciliated epithelial cells that constantly transport this viscous layer towards the bronchi and away from the alveoli to facilitate expulsion of trapped particles [3]. A variety of soluble host defence mediators such as secretory IgA, antimicrobial peptides, surfactant proteins, lactoferrin, and lysozyme also bolster the mucosal

\footnotetext{
* Correspondence: salman.qureshi@mcgill.ca; Markus.Schnare@staff.unimarburg.de

'Division of Experimental Medicine, McGill University, Montréal, Québec H3A 1A3, Canada

${ }^{3}$ Institute of Immunology, Philipps-University of Marburg, Germany

Full list of author information is available at the end of the article
}

defences of the lower respiratory tract. Finally, resident alveolar macrophages (AMs) and airway mucosal dendritic cells (DCs) provide constant surveillance for potentially pathogenic factors while inhibiting $\mathrm{T}$ cell responses to myriad non-pathogenic antigens [4]. These normal host defences ensure that most encounters between the respiratory tract and pathogens are inconsequential; nevertheless, in response to prolonged, intense, or highly virulent microbial exposure, an inflammatory response or productive infection is likely to occur. To rapidly initiate an acute inflammatory response in these circumstances, the lung epithelium, myeloid cells, and associated lymphoid tissue are all equipped with a series of highly conserved pattern recognition receptor (PRRs) including Toll-like receptors (TLRs), NOD-like receptors (NLRs), and RIG-I like receptors (RLRs). PRR activation leads to the release of cytokines and chemokines that attract leukocytes to the site of infection and trigger the maturation and trafficking of antigen presenting cells for induction of adaptive immunity (figure 1). The purpose of this article is to review the role of TLRs in the pathogenesis or consequences of acute lung injury (ALI) and chronic inflammatory lung diseases including asthma, chronic obstructive pulmonary disease (COPD), and cystic fibrosis $(\mathrm{CF})$. 


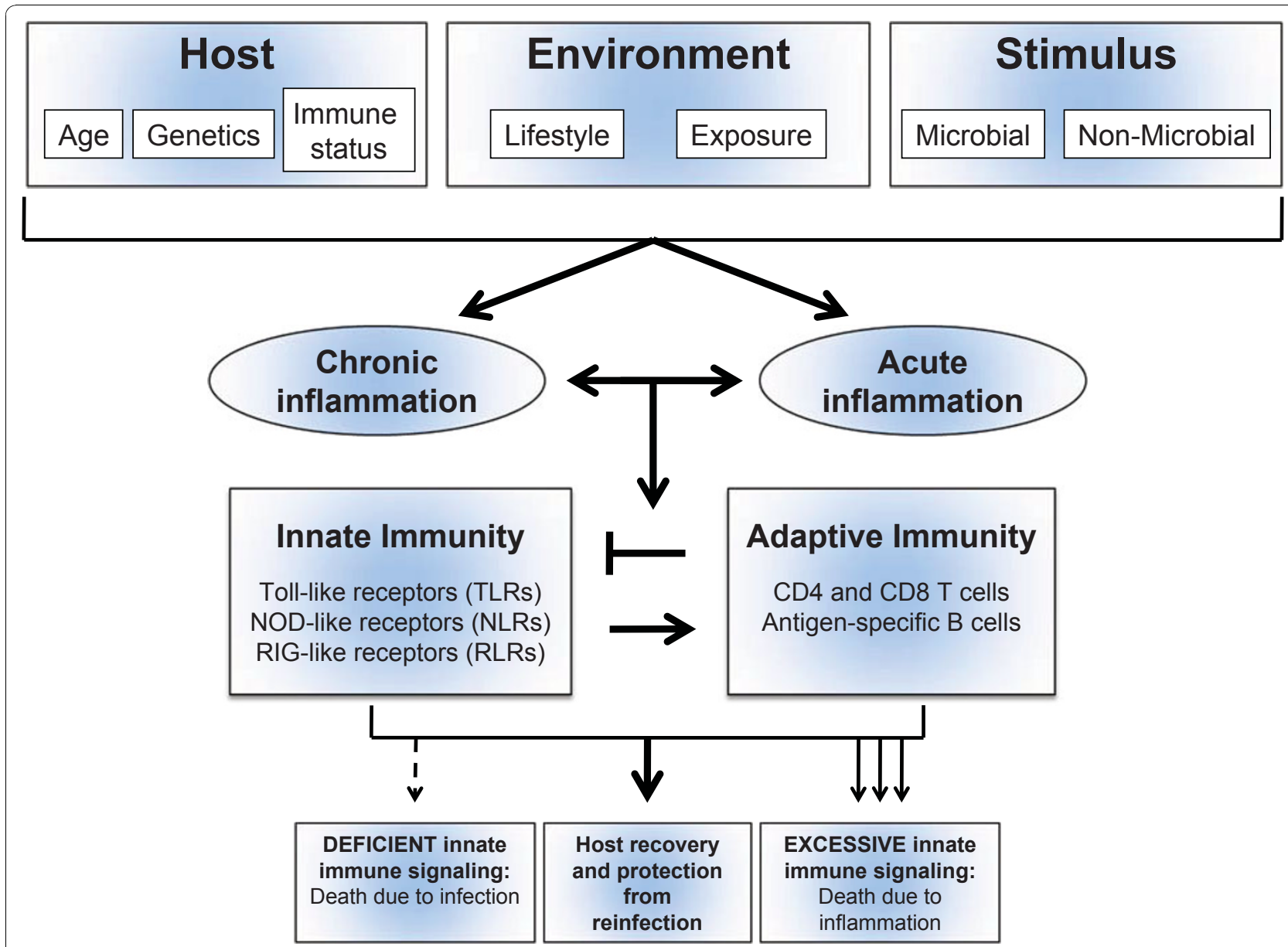

Figure 1 Innate and adaptive immunity in acute and chronic lung inflammation. A variety of host and environmental factors contribute to the development of acute and chronic lung inflammation. Recognition of pathogen associated molecular patterns (PAMPs) or endogenous damage associated molecular patterns (DAMPs) by host pattern recognition receptors (PRRs), including Toll-like receptors (TLRs), elicits innate immune responses that subsequently instruct adaptive immunity. Recovery from the inciting stimulus depends on robust yet tightly regulated innate and adaptive immune responses. Deficient innate immune signaling leads to excess pathogen burden while an exaggerated response can cause severe tissue injury and death of the host.

\section{Ligands of TLRs \\ Microbial ligands}

Constant interactions between the respiratory tract and the environment pose a major challenge to host immunity and necessitate robust surveillance mechanisms to distinguish innocuous from pathogenic exposures. One strategy that is used by TLRs for selective induction of a host response is recognition of unique microbial structures termed pathogen-associated molecular patterns (PAMPs) [5-8]. Eleven functional TLR genes that play diverse roles in host defense, inflammation, autoimmunity, and neoplasia have been discovered in mouse and man (mouse TLR10 is a pseudogene and human TLR11 encodes a truncated protein) [5]. Prototypic examples of PAMPs include lipopolysaccharide (LPS), a outer membrane component of Gram-negative bacteria that stimulates TLR4 [8,9], bacterial lipoproteins that stimulate
TLR2 in conjunction with either TLR1 or TLR6 [10], and flagellin, the protein monomer of bacterial flagella that activates TLR5 [11]. Nucleic acids are recognized by endosomal TLRs; double-stranded DNA with unmethylated CPG motifs activates TLR9 in a host species-specific manner while TLR3 and TLR7/8 are activated by dsRNA including synthetic poly (I:C) [12] and ssRNA, respectively $[13,14]$.

\section{Host-derived ligands}

Following the discovery that TLRs discriminate self from non-self through their intracellular localization or recognition of distinct ligand signatures, evidence was gathered in support of the hypothesis that endogenous host molecules termed danger associated molecular patterns (DAMPs) also stimulate TLRs. The first suggestion of this process came from studies of heat shock protein 
(hsp) [15]; subsequently, a number of other endogenous ligands including the extra domain $\mathrm{A}$ of fibronectin and hyaluronic acid were also shown to activate TLRs $[16,17]$. Recognition of endogenous ligands by TLRs may also contribute to the onset and initiation of autoimmune responses. For example, the high mobility group box protein 1 (HMGB1) protein that normally resides in the cell nucleus can activate TLR2 and induce hallmarks of lupus-like disease when released from apoptotic cells as a complex with nucleosomes [18].

\section{TLR signaling}

The activation of TLRs results in acute inflammation and controls the adaptive immune response at various levels. Partially overlapping intracellular signaling pathways downstream of each TLR activate specific transcription factors that regulate the expression of genes responsible for inflammatory and immune responses. Four adaptors that harbour a Toll-Interleukin-1 Receptor (TIR) domain, including MyD88, TIRAP (MAL), TRIF (TICAM1), and TRAM, connect the TLRs to the cytoplasmic signaling machinery [5]. MyD88 was initially identified as part of the interleukin (IL) $-1 \mathrm{R}$ and IL-18R signalling pathways and was subsequently implicated in signalling by almost all TLRs to trigger NF- $\kappa \mathrm{B}$, Interferon Regulatory Factor (IRF) 5, and Mitogen Activated Protein (MAP) kinase activation. A notable exception is TLR3 that mediates the activation of IRFs exclusively through the adaptor molecule TRIF [19]. The function of TIRAP is to recruit MyD88 to TLR2 and TLR4 at the plasma membrane, while TRAM recruits TRIF to TLR4 for activation of IRF3. A fifth adaptor protein, SARM, negatively regulates TRIF-dependent signaling [20,21]. Activation of different intracellular signaling mechanisms through TLRs results in the induction of distinct gene programs and cytokine expression patterns that control the recruitment of downstream molecules and regulate the identity, strength, and kinetics of gene and protein expression. More detailed reviews of the TLR signalling pathways have been published elsewhere [22-24].

The potent stimulatory responses mediated by TLR signaling must be tightly regulated at numerous levels in order to prevent the deleterious consequences of excessive innate immune activation [25]. For example, soluble forms of TLR4 and TLR2 may function as decoy receptors to terminate ligand interactions with membrane bound TLRs [26]. Furthermore, IRAK-M has 30-40\% homology to the other IRAK-family members and stabilizes the TLR-MyD88-IRAK4 complex, leading to a unique negative regulatory influence on TLR signaling $[27,28]$. TLR signaling is also inhibited by transmembrane receptors like ST2, SIGIRR, and TRAILR while proteins such as Tollip [29], SARM [21], an inducible splice variant of MyD88 (MyD88s) [30], and the suppressor of cytokine signaling 1 (SOCS1) [31] are responsible for modulation of intracellular TLR signaling.

In addition to TLRs, a variety of other PRRs including the cytoplasmic NLRs and RLRs play important roles in the induction of lung inflammation. For example, the cytoplasmic NALP3 protein, a member of the NLR family that triggers assembly of the caspase- 1 inflammasome and production of mature IL-1 $\beta$, was recently implicated in the development of asbestos or silica-induced pulmonary fibrosis [32]. RLRs on immune and non-immune cells recognize viral RNA species and induce host responses through the adaptor IPS-1. Several putative cytosolic detectors of double-stranded DNA including DAI (ZBP1DLM1) and AIM2 have also been identified; however their roles in lung diseases have not been established. A detailed discussion of these important non-TLR innate immune receptors is beyond the scope of this article; however, interested readers may consult other sources [33].

\section{Expression and function of TLRs in lung cells or tissue}

TLRs are widely expressed on both resident lung cells as well as infiltrating cells of myeloid and lymphoid origin. Primary bronchial epithelial cells express mRNA for TLR1-10 and secrete the chemokine CXCL8 (IL-8) in response to various TLR ligands [34]. Human AMs have been shown to express low levels of TLR3, TLR5, and TLR9 and higher levels of TLR1, TLR2, TLR4, TLR7, and TLR8 $[35,36]$. Lung endothelial cells express TLR4 that is crucial for neutrophil recruitment and capillary sequestration following systemic LPS administration [37]. Neutrophils that localize to the lung vasculature in response to LPS express TLR1, TLR2, TLR4, TLR5, and TLR9 [38]. Several DC subsets have been identified in the mouse and human lung and can be distinguished according to their surface marker expression and anatomical location $[39,40]$. Lung DCs act as sentinels that are activated by TLR ligation in order to bridge innate and adaptive immunity. Lung plasmacytoid DCs (pDCs) express uniquely high levels of TLR7 and TLR9 that suppress the allergic response and regulatory lung DCs give rise to regulatory T cells [41]. Notably, in some cases the level of TLR transcription in cells does not correlate with functional responses [35,36]. For example, following stimulation with LPS or mycobacterial DNA, human AMs produced higher levels of the inflammatory cytokine TNF- $\alpha$ while interstitial macrophages produced higher levels of the immunoregulatory cytokines IL-6 and IL-10 despite similar levels of TLR mRNA [35]. Finally, lung tissue cells may also be activated through cooperative interactions with TLR responsive lymphoid cells, as exemplified by airway smooth muscle cell activation via IL-1 $\beta$ release from LPS-stimulated monocytes [42]. Thus, 
responsiveness to TLR ligands in the lung is shaped by cell intrinsic mechanisms as well as cooperative actions of both resident and recruited cell populations.

\section{Acute Lung Injury (ALI)/Acute Respiratory Distress Syndrome (ARDS)}

ALI or ARDS is a life-threatening condition that is characterized by increased inflammatory cytokine expression and cell infiltration into the lungs, non-cardiogenic pulmonary edema, and diffuse alveolar damage that culminates in respiratory failure $[43,44]$. ALI can be a consequence of bacterial or viral infection or may be triggered by non-infectious insults including environmental toxin exposure (ozone, heavy metals), trauma, or hyperoxia. TLRs mediate ALI through recognition of microbial PAMPs or through detection of endogenous DAMPs (hsp, hyaluronan, fibrinogen, HMGB1 [16,45-50], both of which trigger inflammation [51-57]. Depending on the specific nature and intensity of the inciting stimulus, this response can be beneficial (maintenance of tissue integrity and repair) or detrimental (increased fibrosis and fluid in the lungs) for host recovery (figure 1) $[43,57,58]$. In this review we will focus on the contribution of TLR signaling to a subset of clinically relevant causes of ALI.

\section{Non-infectious causes of ALI/ARDS}

Hemorrhagic shock (HS) is common in trauma patients and can prime the host immune response to elicit excessive inflammation, neutrophil influx and tissue injury in response to a secondary stimulus, causing ALI through the so-called 'two-hit hypothesis' [59-61]. Well characterized mouse models of HS-induced ALI using LPS as the secondary stimulus have determined that cross talk between TLR2 and TLR4 elicits heightened inflammatory mediator expression, such as CXCL1, leading to increased neutrophil influx and pulmonary edema [55,60,62-64]. Early inflammation in HS-induced ALI is dependent on upregulation of TLR4 by LPS, while later inflammation is mediated by heightened TLR2 expression on AMs and endothelial cells [64]. Deletion of either TLR2 or TLR4 in mice conferred protection from ALI and confirmed the presence of cross talk between these two receptors $[63,65]$.

Hyperoxia (high concentrations of inspired oxygen) is a common therapy in critically ill patients; however, this treatment can also cause severe ALI by upregulating the production of reactive oxygen species [44,66-69]. TLR4 protects the host from hyperoxia-induced ALI by maintaining lung integrity and inducing the expression of protective anti-apoptotic factors such as Bcl2 and Phospho-Akt [70,71]. TLR4 or TLR2/TLR4 double knockout mice exposed to hyperoxia have significantly greater lung inflammation and permeability and are more susceptible to lethal ALI compared to wild type mice
[71,72]. Conversely, TLR3-deficient mice are protected from ALI due to decreased neutrophil recruitment, induction of pro-apoptotic factors, and increased surfactant protein expression that clears injury-induced cellular debris [73-75].

Bleomycin is a potent anticancer agent that ultimately leads to cell death through generation of oxygen radicals and DNA breaks [76]. Bleomycin toxicity is usually associated with diffuse pulmonary fibrosis but may also cause ALI by triggering the degradation of high molecular weight hyaluronan (HA) in the extracellular matrix [77-79]. In contrast to intact HA that mediates homeostasis, accumulation of low molecular weight HA fragments is detrimental because it induces relentless pulmonary inflammation in AMs [72,78]. Loss of TLR2 and TLR4 or the adaptor molecule MyD88 leads to increased tissue injury, epithelial cell apoptosis and decreased survival following bleomycin exposure as well as decreased chemokine expression and defective neutrophil recruitment to the lungs [72]. Further mechanistic studies showed that TLR2 and TLR4 not only trigger basal NF- $\kappa \mathrm{B}$ activation at the lung epithelium through interactions with intact $\mathrm{HA}$ in order to maintain cell integrity and decrease lung injury, but also mediate macrophage inflammatory responses to HA fragments following chemically induced tissue injury $[72,80]$.

\section{Infectious causes of ALI/ARDS}

Pneumonia is the most common cause of ALI or ARDS [81]. During the past decade, novel and highly virulent respiratory viruses, such as the Severe Acute Respiratory Syndrome Coronavirus (SARS CoV), have emerged as important causes of excessive lung damage in infected humans [82]. The 2003 global SARS epidemic had a $50 \%$ mortality rate with $16 \%$ of all infected individuals developing ALI $[83,84]$. The lung pathology in these patients mirrored ALI caused by other factors, consisting primarily of diffuse alveolar damage caused by virusalveolar cell interaction [85]. The contribution of TLRs to SARS pathogenesis is not well understood [86]; however, using different mouse models of related $\mathrm{CoV}$ infection, a protective role for TLR4 [87] and MyD88 [88] has been suggested while TLR7 may be important for viral clearance through production of type I IFN [89].

Highly pathogenic strains of influenza virus are another important cause of ALI/ARDS in humans. Compared to seasonal influenza strains that bind cells of the upper respiratory tract, highly pathogenic $\mathrm{H} 5 \mathrm{~N} 1$ influenza virus infects alveolar type II cells, macrophages, and nonciliated cuboidal epithelium of the terminal bronchi leading to a lower respiratory tract infection and ALI/ARDS [90,91]. Modeling of H5N1 infection in mice reproduced the pattern of damage seen in humans including increased neutrophilia, alveolar and interstitial edema, 
lung hemorrhage, and elevated TNF- $\alpha$ and IL- 6 expression in the airway lining fluid $[92,93]$. Mice that survived beyond the acute phase of infection had large regions of lung interstitial and intra-alveolar fibrosis and ALI [93].

The role of TLRs has been intensively studied in influenza infection. TLR7 expression on pDCs plays a cell-specific role against influenza through MyD88dependent IFN- $\alpha$ induction $[13,94]$. Despite the importance of TLR7/MyD88 signaling, MyD88-deficient mice can still produce type I IFN, control viral replication, and recover from the infection [95]. An increased lung viral load was seen only when MyD88 and IPS-1 (the adaptor molecule for the cytosolic RIG-I pathway) were both absent, suggesting that these pathways can compensate for one another during influenza infection [95]. Though not essential for survival, MyD88 does play a distinct role in the adaptive immune response to influenza through regulation of B-cell isotype switching $[95,96]$.

The role of TLR3 in the immune response to influenza has been debated in the literature. Although several studies have shown that dsRNA is not produced during influenza replication [97,98], very low and potentially undetectable levels of this viral intermediate could still elicit a substantial immune response through TLR3 $[99,100]$. The finding that TLR3 is upregulated in human bronchial and alveolar epithelial cells during influenza infection suggests that it may play an important role in immune signaling [101]. Deletion of TLR3 leads to downregulation of inflammatory cytokine and chemokine production and an elevated viral load during the late phase of influenza infection. Surprisingly, TLR3 mutant mice have an increased survival rate compared to wild type mice suggesting that TLR3 signaling is detrimental to the host, despite its role in reducing viral replication [102,103]. In addition to the TLRs, RIG-I, NLRP3, and NOD2 have also been implicated in the immune response to influenza [104-108]; however, the relative contribution of these PRRs to influenza-specific host defense requires additional study.

\section{TLRs in chronic pulmonary diseases Cystic Fibrosis (CF)}

$\mathrm{CF}$ is an autosomal recessive disorder caused by mutations in the cystic fibrosis transmembrane conductance regulator (CFTR) gene [109]. The airways of CF patients are characterized by chronic bacterial colonization and associated neutrophilic inflammation. P. aeruginosa infection is the major cause of morbidity and mortality among CF-affected individuals, producing acute pneumonia or chronic lung disease with periodic acute exacerbations $[3,110,111]$. A predisposition to chronic and progressive $P$. aeruginosa infection occurs despite the finding that both CF and non-CF lung epithelial cells express functional TLRs that can mediate inflammatory responses to microbes. For example, in one study comparing human CFTE29o (trachea; homozygous for the delta F508 CFTR mutation) and 16HBE14o (bronchial non-CF) cells, comparable mRNA and surface protein expression of TLR1-5 and TLR9 was observed [112]. TLR6 mRNA, but not protein, expression was observed in both cell lines; however, for unclear reasons only the CF line responded to TLR2/TLR6 agonist MALP-2 [112]. Despite this similar TLR expression pattern, a more recent study showed increased inflammatory responses following stimulation with clinical Pseudomonas isolates in a CF airway epithelial cell line (IB3-1) compared to a "CF-corrected" line stably expressing wild type CFTR [113]. A detailed analysis showed that these responses were dependent on bacterial flagellin and TLR5 expression. Peripheral blood mononuclear cells from CF patients also responded more vigorously to stimulation with $P$. aeruginosa and TLR ligands compared to healthy controls and expressed higher levels of TLR5 mRNA, suggesting that CFTR mutations modulate the host inflammatory response through undetermined mechanisms [113]. In another study, a selective increase in TLR5 expression was found on airway, but not circulating, neutrophils from CF patients compared to patients with bronchiectasis and healthy control subjects [38]. The functional relevance of neutrophil TLR5 expression was reflected by its correlation with lung function values in $P$. aeruginosa-infected CF patients. Neutrophils also had increased flagellin dependent IL-8 secretion, phagocytosis, and respiratory burst activity that were attributed to chronic infection rather than as a primary consequence of mutant CFTR [38]. TLR5-deficient mice showed impaired bacterial clearance, reduced airway neutrophil recruitment and MCP-1 production after low dose challenge with flagellated $P$. aeruginosa that was not observed after challenge with an isotypic non-flagellated strain, confirming a specific contribution of TLR5-dependent pathways to the host inflammatory response [114].

In addition to TLR5-dependent recognition of flagellin, $P$. aeruginosa LPS is detected by TLR4 and the $P$. aeruginosa ExoS toxin is recognized by both TLR2 and TLR4 [11,115-117]. Loss of a single TLR does not confer susceptibility to $P$. aeruginosa infection while deletion of the adaptor molecule MyD88 does confer hypersusceptibility, increased lung bacterial load, and deficient neutrophil recruitment [114,117-123]. Interestingly, MyD88 may play an essential role only during the early phase of infection (4-8 hours) as inflammation and control of bacterial load 48 hours after low dose infection occurred through an undetermined MyD88-independent mechanism [119]. Both TLR2 and TLR4 signal through MyD88-dependent and -independent pathways while TLR5 signals exclusively through MyD88. Studies to determine the relative contribution of TLR2, TLR4, and TLR5 have had conflicting 
results, possibly due to the complex pathogenesis of pseudomonal infection [123-125].

Staphylococcus aureus and Burkholderia cenocepacia have been associated with early and advanced CF lung disease, respectively [3]. B. cenocepacia provokes lung epithelial damage and TNF- $\alpha$ secretion that leads to severe pneumonia and sepsis in CF patients [126,127]. Excess inflammation and mortality in B. cenocepacia infection occurred through flagellin-dependent activation of TLR5 and MyD88 [128,129]. Another study showed that, despite higher bacterial load, MyD88-deficient mice had less inflammation and decreased mortality compared to wild type mice infected with B. cenocepacia [130].

\section{Chronic Obstructive Pulmonary Disease (COPD)}

COPD includes disorders of the respiratory system that are characterized by abnormal inflammation as well as expiratory airflow limitation that is not fully reversible. In humans, the main risk factor for COPD is smoking and the disease prevalence rises with age [131]. Although the pathogenesis of COPD is not well understood, various aspects of lung innate immunity are impaired including mucociliary clearance, AM function, and expression of airway antimicrobial polypeptides [132]. As a result, microbial pathogens frequently establish residence in the lower respiratory tract and induce a vicious circle of inflammation and infection that may contribute to progressive loss of lung function [133] (figure 1).

There is accumulating evidence that impaired innate immunity is likely to contribute to the pathogenesis of COPD [134]. An essential role for TLRs in the maintenance of lung structural homeostasis under ambient conditions was recently described [135]. In this study, TLR4- and MyD88-deficient mice developed spontaneous age-related emphysema that was associated with increased oxidant stress, cell death, and elastolytic activity. A detailed mechanistic analysis showed that TLR4 maintains a critical oxidant/antioxidant balance in the lung by modulating the expression and activity of NADPH oxidase 3 in structural cells. In light of this finding, the free radicals and oxidant properties of tobacco smoke have been hypothesized to subvert innate immunity and cause lung cell necrosis and tissue damage $[136,137]$. Indeed, mice with short-term cigarette smoke exposure develop neutrophilic airway inflammation that is dependent on TLR4, MyD88, and IL-1R1 signaling [138]. Consistent with these findings, $\mathrm{C} 3 \mathrm{H} / \mathrm{HeJ}$ mice that have naturally defective TLR4 signaling develop less chronic inflammation after 5 weeks of cigarette smoke exposure [139]. Finally, long-term cigarette smoke exposure induced strain-dependent emphysema in mice in one study, although no specific association to TLRs was described [140].
Several studies have evaluated TLR expression and function in AMs from COPD patients, smokers, and non-smokers. Using flow cytometry, one group showed reduced TLR2 expression on AMs of COPD patients and smokers compared to non-smokers following ex vivo ligand stimulation. Upregulation of TLR2 mRNA and protein expression was observed only in AMs from nonsmokers while no significant differences in TLR4 expression were demonstrated among these three groups [141]. Another report showed comparable AM expression of TLR2, TLR4 or the co-receptors MD-2 or CD14 between smokers and non-smokers [142], yet AM stimulation with TLR2 or TLR4 ligands elicited lower mRNA and protein expression of inflammatory cytokines (TNF- $\alpha$, IL-1 $\beta$, IL-6) or chemokines (IL-8, RANTES) in smokers that was associated with suppressed IRAK-1 and p38 phosphorylation and impaired NF- $\kappa$ B activation [142]. From this data, the authors concluded that chronic LPS exposure via cigarette smoking selectively reprograms AMs and alters the inflammatory response to TLR2 and TLR4 ligands [142]. Finally, another study showed reduced TLR4 mRNA expression in nasal and tracheal epithelial cells of smokers compared to healthy nonsmoking control subjects with no differences in TLR2 expression [143]. Relative to non-smokers, patients with mild or moderate COPD showed increased expression of TLR4 and HBD-2, a TLR4 inducible antimicrobial peptide, while those with advanced COPD had a reduction in TLR4 and HBD-2 expression [143]. Modulation of TLR4 expression by cigarette smoke extract was studied in vitro and revealed a dose-dependent reduction in TLR4 mRNA and protein expression as well as reduced IL-8 secretion in the A549 alveolar epithelial cells [143]. Taken together, these findings point to dynamic regulation of airway epithelial and AM TLRs in response to diverse environmental stimuli. The differences in TLR expression across studies could be related to variable LPS content in tobacco smoke, bacterial colonization, or a persistent inflammatory state. Increased TLR4 expression in mild or moderate COPD may reflect a robust host response, while the decreased TLR4 expression level in association with severe COPD may reflect a loss of innate immunity or an adaptive regulatory response.

The interaction of cigarette smoke and PRR activation has been studied using mouse models. In one study, AMs from mice that had been exposed to cigarette smoke for eight weeks showed decreased cytokine (TNF- $\alpha$, IL-6) and chemokine (RANTES) production following in vitro stimulation with double-stranded RNA, LPS, or NLR agonists [144]. No alteration of TLR3 or TLR4 expression was observed; however, there was decreased nuclear translocation of the transcription factor NF- $\kappa \mathrm{B}$. The functional impairment of cytokine release was specific to 
AMs and reversible after cessation of smoke exposure [144]. A subsequent report found a synergistic interaction of cigarette smoke and dsRNA or influenza virus that leads to emphysema in mice through epithelial and endothelial cell apoptosis as well as proteolysis [145]. This process was mediated by IL-12, IL-18, and IFN- $\gamma$ as well as activation of antiviral response pathways including the intracellular signaling adaptor protein IPS-1 and the kinase PKR.

Defective innate immunity may predispose to acute exacerbations of COPD that are characterized by acutely worsening dyspnea, cough, sputum production, and accelerated airflow obstruction [146]. Bacterial colonization (Streptococcus pneumoniae, Haemophilus influen$z a e$ ) or viral infection (Influenza A and B, Respiratory Syncytial Virus) of the lower respiratory tract are primary causes of acute COPD exacerbations [146-152]. Virulent pneumococci express the toxin pneumolysin that is able to physically interact with TLR4 [153-159]. Consistent with this finding, nasopharyngeal infection of TLR4-deficient mice with S. pneumoniae causes enhanced bacterial load, dissemination, and death compared to wild type mice [158]. Interestingly, the role of TLR4 seems to be specific to the nasopharynx as TLR4deficient mice exhibit only a modest impairment of host defense following direct pneumococcal infection of the lower respiratory tract [160]. TLR2 is also upregulated following pneumococcal infection and enhances host inflammatory responses $[161,162]$. Despite a modest reduction of inflammatory mediator production, TLR2deficient mice can still clear high and low infectious doses of S. pneumoniae, suggesting that another PRR compensates for the loss of TLR2 in this model $[160,163]$. TLR9-deficient mice are slightly more susceptible to pneumococcal infection compared to wild type animals [164]. Conversely, abrogation of MyD88 signaling leads to uncontrolled airway pneumococcal growth, systemic bacterial dissemination and decreased immune mediator (TNF- $\alpha$ and IL-6) expression $[158,165,166]$. The severe susceptibility phenotype of MyD88-deficient mice compared to mice with a single deletion of TLR9 or combined deletion of TLR2 and TLR4 highlights the crucial role of this downstream adaptor in host defense against S. pneumoniae $[158,160,163,164,167]$.

Non-typeable $H$. influenzae (NTHi) is another bacterium that commonly colonizes the respiratory epithelium and causes COPD exacerbations [168-171]. While NTHi produces both TLR4 and TLR2 ligands, TLR4/MyD88 is the dominant immune signaling pathway in vitro and mediates bacterial clearance in vivo [172]. TLR4 signaling in response to NTHi is entirely MyD88 dependent as TRIF KO mice had an identical bacterial load compared to wild type mice [172]. TLR3 may also play a role in inflammatory mediator production in the immune response to NTHi although its relative contribution to bacterial clearance is not clear [173].

\section{Asthma}

Asthma is a potentially life-threatening chronic inflammatory airway disease that is characterized by episodic bronchoconstriction, mucus hypersecretion, goblet cell hyperplasia and tissue remodelling that may begin in childhood. The underlying immune response in asthma is targeted against environmental antigens including pollen or dust particles and is characterized by the presence of antigen-specific Th2 cells in the lung that facilitate production of antigen specific IgE $[174,175]$. Viral and bacterial infections have been associated with induction or protection against asthma, suggesting that innate immunity plays an important role in disease pathogenesis [176]. On the basis of several epidemiologic, human, and animal studies, the timing and extent of LPS exposure, and presumably TLR4 activation, appears to determine whether a protective Th1 response or a permissive Th2 response develops in the lung [177]. For example, it was demonstrated that low dose administration of intranasal LPS induces a Th2 biased immune response in the lung whereas elsewhere in the body LPS is a strong inducer of a Th1 immune response [178]. Nevertheless, experimental treatment of mice with microbes [179] or TLR agonists [180,181] inhibits allergic sensitization, eosinophilic inflammation, and airways hyperresponsiveness. Recently, experimental intranasal infection of pregnant mice with Acinetobacter lwoffii F78 was shown to confer protection against ovalbumin-induced asthma in the progeny. Using knockout mice, the protective effect was shown to be dependent on maternal TLR expression and suggests that microbial recognition during pregnancy somehow primes the fetal lung environment for a Th1 response later in life [182].

Lung resident cells that express TLR4 also play an important role in the induction of allergen specific Th2 cells via recognition of house dust mite (a ubiquitous indoor allergen) that leads to the production of thymic stromal lymphopoietin, granulocyte-macrophage colonystimulating factor, IL-25 and IL-33. This cytokine milieu can bias lung DCs towards a Th2 activating phenotype that drives the polarization of naïve lymphocytes [183]. In addition, eosinophil derived neurotoxin can induce TLR2-dependent DC maturation, leading to Th2 polarization by secretion of high amounts of IL- 6 and IL-10 [184] while basophils may also instruct $\mathrm{T}$ cells to become Th2 cells [185].

TLRs have been shown via genetic association studies as well as single and multiple gene knockout studies to play a role in the development of allergic asthma. For example TLR7 and TLR8 are associated with human asthma [186] while ligands of TLR7 and TLR8 can 
prevent airway remodeling caused by experimentally induced asthma $[187,188]$. TLR10 single nucleotide polymorphisms have also been associated with asthma in two independent samples [189] although the ligand for TLR10 has not been defined. Finally, in a multicentre asthma study, TLR4 and TLR9 were both associated with wheezing and TLR4 was also associated with allergen specific IgE secretion [190]. Based on this observation, TLR9 ligands are currently in clinical trials for the treatment or prevention of asthma [191].

Asthma can be further exacerbated by bacterial respiratory tract infection including Mycoplasma pneumoniae or Chlamydophila pneumoniae [192]. In one study, $50 \%$ of patients suffering from their first asthmatic episode were infected with $M$. pneumoniae while $10 \%$ were serologically positive for acute C. pneumoniae infection [193,194]. MyD88-deficient mice infected with C. pneumoniae failed to upregulate cytokine and chemokine expression, had delayed $\mathrm{CD}^{+}$and $\mathrm{CD} 4^{+} \mathrm{T}$ cell recruitment, and could not clear the bacterium from the lungs leading to severe chronic infection and significantly increased mortality [195]. At a later stage of infection, IL-1 $\beta$, IFN- $\gamma$ and other inflammatory mediators may be upregulated via a MyD88-independent pathway but are not sufficient to prevent mortality from C. pneumoniae [195]. TLR2 and TLR4-deficient mice can recover from $C$. pneumoniae infection with no impairment of bacterial clearance suggesting that other PRRs are also involved in host defense or that TLR2/ TLR4 act in concert during C. pneumoniae infection [195,196].

TLR2 is also upregulated in response to M. pneumoniae infection, leading to increased expression of airway mucin $[197,198]$. Allergic inflammation along with the induction of Th2 cytokines (IL-4, IL-13) leads to TLR2 inhibition during $M$. pneumoniae infection, thereby decreasing the production of IL- 6 and other Th1 proinflammatory mediators that are required for bacterial clearance [199]. Antibiotic treatment of asthmatic patients infected with $M$. pneumoniae improves their pulmonary function and highlights the increasingly important role that bacterial colonization and interactions with the host innate immune response play in asthma exacerbations and mortality $[200,201]$.

Viral infection of the lower respiratory tract can also contribute to asthma development and exacerbations. Respiratory Syncytial Virus (RSV) is a particularly important cause of acute bronchiolitis and wheezing in children that may lead to the subsequent development of asthma [202-206]. Wheezing after the acquisition of severe RSV infection early in life has been associated with elevated Th2 responses, eosinophilia, and IL-10 production [207-211]. During RSV infection, the viral G protein mediates attachment to lung epithelial cells and the $\mathrm{F}$ protein leads to the fusion of the viral envelope with the host cell plasma membrane [212]. In response to RSV infection, TLRs are broadly upregulated in the human tracheal epithelial cell line 9HTEo [213]. In mice, TLR4 has been shown to recognize the $\mathrm{F}$ protein and activate NF- $\kappa$ B during RSV infection [203,214]. Accordingly, TLR4-deficient animals exhibit impaired NK cell function and increased viral load [205,215]. Defective TLR4 signalling has also been linked to increased pathology in a study of pre-term infants [216]. An essential role for IL-12, rather than TLR4, in susceptibility to RSV has also been proposed [214]; however, significant differences in experimental design limit the comparison of these apparently discordant studies [217].

In human lung fibroblasts and epithelial cells, the formation of dsRNA during RSV replication can activate TLR3-mediated immune signaling, leading to the upregulation of the chemokines RANTES and IP-10 [218]. TLR3-deficient mice have a predominantly Th2 response to RSV characterized by increased airway eosinophilia, mucus hypersecretion and expression of IL-5 and IL-13 [219]. RIG-I-induced IFN- $\beta$ expression during RSV infection was recently shown to trigger TLR3 activation, suggesting that TLR3 mediates a secondary immune signaling pathway [220]. Interestingly, while TLR3 is involved in chemokine expression it has no role in RSV viral clearance, which is primarily mediated by the TLR2/TLR6 heterodimer $[218,219]$.

In summary, the emerging picture of allergic asthma suggests that the disease can be mediated or exacerbated in genetically predisposed individuals by infection. In some cases these infections may induce an inflammatory state that protects against asthma, while in others the infection may elicit an acute allergic response or bias the host towards a subsequent Th2 response (figure 1).

\section{Conclusion}

Innate immunity is a principal mechanism for the maintenance of lung tissue homeostasis despite continuous exposure to environmental irritants and potentially pathogenic microorganisms. In recent years tremendous progress has been made with regard to how the TLRs contribute to host defence and tissue repair. The insights that have arisen from this work allow one to postulate a few general principles with regard to lung innate immunity. First, acute pulmonary diseases such as ALI and bronchiolitis frequently develop into chronic inflammatory states (fibroproliferative ARDS) or exhibit a relapsing and remitting pattern (asthma). Second, infectious diseases are principal causes of sustained lung inflammation, as exemplified by severe influenza pneumonia that progresses to ARDS or severe RSV infection that precedes the development of asthma. Third, defective innate immunity contributes to the development of 
chronic obstructive lung diseases while directly or indirectly predisposing the host to infection, as observed in CF patients with chronic $P$. aeruginosa infection or acute exacerbations of COPD caused by S. pneumoniae. Finally, tissue repair and remodelling are crucial to the pathogenesis of lung inflammation as well as to host defense, and based on current data it appears that TLRdependent mechanisms mediate the development of both processes.

Despite extensive research, many questions remain unanswered, including the relative contributions of TLR and non-TLR PRRs to lung inflammation and protective immunity, the precise nature of gene-environment interactions in asthma pathogenesis, the molecular mechanisms that negatively regulate the innate immune response during ALI, the failure of innate immunity to sterilize the lower respiratory tract in $\mathrm{CF}$, and the role of innate immunity in tissue remodelling in asthma and COPD. A deeper understanding of the basic biology of TLRs will provide additional opportunities to elucidate the links between innate immunity and the development of acute and chronic inflammatory or infectious lung diseases. Ultimately, it is our hope that such knowledge will provide new strategies to limit the burden of human suffering and death due to respiratory disease.

\section{Acknowledgements}

This work is supported by a McGill University Faculty of Medicine studentship (EIL), a Canada Research Chair (SQ), grants from the Canadian Institutes of Health Research (SQ), a grant from the Fonds de la recherche en santé du Québec to the Research Institute of the McGill University Health Centre and a grant from the German Research Foundation (MS).

\section{Author details}

${ }^{1}$ Division of Experimental Medicine, McGill University, Montréal, Québec H3A 1A3, Canada. ${ }^{2}$ Department of Medicine, McGill University, Montréal, Québec H3A 1A1, Canada. ${ }^{3}$ Institute of Immunology, Philipps-University of Marburg, Germany.

\section{Authors' contributions}

E.I.L., S.T.Q., and M.S. wrote the manuscript and approved the final text.

\section{Competing interests}

The authors declare that they have no competing interests.

Received: 7 July 2010 Accepted: 25 November 2010 Published: 25 November 2010

\section{References}

1. Mizgerd JP: Lung infection-a public health priority. PLOS Med 2006, 3(2): e76.

2. Mizgerd JP: Acute lower respiratory tract infection. N Engl J Med 2008, 358(7):716-727.

3. Campodonico VL, Gadjeva M, Paradis-Bleau C, Uluer A, Pier GB: Airway epithelial control of Pseudomonas aeruginosa infection in cystic fibrosis. Trends Mol Med 2008, 14(3):120-133.

4. Holt PG, Strickland DH, Wikstrom ME, Jahnsen FL: Regulation of immunological homeostasis in the respiratory tract. Nat Rev Immunol 2008, 8(2):142-152

5. Takeda K, Akira S: TLR signaling pathways. Semin Immunol 2004, 16(1):3-9.
6. Lemaitre B, Nicolas E, Michaut L, Reichhart JM, Hoffmann JA: The dorsoventral regulatory gene cassette spatzle/Toll/cactus controls the potent antifungal response in Drosophila adults. Cell 1996, 86(6):973-983.

7. Medzhitov R, Preston-Hurlburt P, Kopp E, Stadlen A, Chen C, Ghosh S, Janeway CA Jr: MyD88 is an adaptor protein in the hToll/IL-1 receptor family signaling pathways. Mol Cell 1998, 2(2):253-258.

8. Poltorak A, He X, Smirnova I, Liu MY, Van Huffel C, Du X, Birdwell D, Alejos E, Silva M, Galanos C, Freudenberg M, Ricciardi-Castagnoli P, Layton B, Beutler B: Defective LPS signaling in C3H/HeJ and C57BL/ 10ScCr mice: mutations in Tlr4 gene. Science 1998, 282(5396):2085-2088.

9. Qureshi ST, Lariviere L, Leveque G, Clermont S, Moore KJ, Gros P, Malo D: Endotoxin-tolerant mice have mutations in Toll-like receptor 4 (T/r4). J Exp Med 1999, 189(4):615-625.

10. Takeuchi O, Kawai T, Muhlradt PF, Morr M, Radolf JD, Zychlinsky A, Takeda K, Akira S: Discrimination of bacterial lipoproteins by Toll-like receptor 6. Int Immunol 2001, 13(7):933-940.

11. Hayashi F, Smith KD, Ozinsky A, Hawn TR, Yi EC, Goodlett DR, Eng JK, Akira S, Underhill DM, Aderem A: The innate immune response to bacterial flagellin is mediated by Toll-like receptor 5 . Nature 2001, 410(6832):1099-1103.

12. Alexopoulou L, Holt AC, Medzhitov R, Flavell RA: Recognition of doublestranded RNA and activation of NF-kappaB by Toll-like receptor 3. Nature 2001, 413(6857):732-738.

13. Diebold SS, Kaisho T, Hemmi H, Akira S, Reis e Sousa C: Innate antiviral responses by means of TLR7-mediated recognition of single-stranded RNA. Science 2004, 303(5663):1529-1531.

14. Heil $F$, Hemmi $H$, Hochrein $H$, Ampenberger $F$, Kirschning C, Akira S, Lipford G, Wagner H, Bauer S: Species-specific recognition of singlestranded RNA via toll-like receptor 7 and 8. Science 2004, 303(5663):1526-1529.

15. Erridge C: Endogenous ligands of TLR2 and TLR4: agonists or assistants? J Leukoc Biol 2010, 87(6):989-999.

16. Termeer C, Benedix F, Sleeman J, Fieber C, Voith U, Ahrens T, Miyake K, Freudenberg M, Galanos C, Simon JC: Oligosaccharides of Hyaluronan activate dendritic cells via toll-like receptor 4. J Exp Med 2002, 195(1):99-111.

17. Tsan MF, Gao B: Endogenous ligands of Toll-like receptors. J Leukoc Biol 2004, 76(3):514-519.

18. Urbonaviciute V, Furnrohr BG, Meister S, Munoz L, Heyder P, De Marchis F, Bianchi ME, Kirschning C, Wagner H, Manfredi AA, Kalden JR, Schett G, Rovere-Querini $P$, Herrmann M, Voll RE: Induction of inflammatory and immune responses by HMGB1-nucleosome complexes: implications for the pathogenesis of SLE. J Exp Med 2008, 205(13):3007-3018.

19. Yamamoto M, Sato S, Mori K, Hoshino K, Takeuchi O, Takeda K, Akira S: Cutting edge: a novel Toll/IL-1 receptor domain-containing adapter that preferentially activates the IFN-beta promoter in the Toll-like receptor signaling. J Immunol 2002, 169(12):6668-6672.

20. Carty M, Goodbody R, Schroder M, Stack J, Moynagh PN, Bowie AG: The human adaptor SARM negatively regulates adaptor protein TRIFdependent Toll-like receptor signaling. Nat Immunol 2006 7(10):1074-1081.

21. Barton GM, Kagan JC: A cell biological view of Toll-like receptor function: regulation through compartmentalization. Nat Rev Immunol 2009, 9(8):535-542

22. Kawai T, Akira S: TLR signaling. Semin Immunol 2007, 19(1):24-32

23. Lee MS, Kim YJ: Signaling pathways downstream of pattern-recognition receptors and their cross talk. Annu Rev Biochem 2007, 76:447-480.

24. O'Neill LA, Bowie AG: The family of five: TIR-domain-containing adaptors in Toll-like receptor signalling. Nat Rev Immunol 2007, 7(5):353-364.

25. O'Neill LA: Targeting signal transduction as a strategy to treat inflammatory diseases. Nat Rev Drug Discov 2006, 5(7):549-563.

26. Iwami Kl, Matsuguchi T, Masuda A, Kikuchi T, Musikacharoen T, Yoshikai $Y$ : Cutting edge: naturally occurring soluble form of mouse Toll-like receptor 4 inhibits lipopolysaccharide signaling. J Immunol 2000, 165(12):6682-6686

27. Deng JC, Cheng G, Newstead MW, Zeng X, Kobayashi K, Flavell RA, Standiford TJ: Sepsis-induced suppression of lung innate immunity is mediated by IRAK-M. J Clin Invest 2006, 116(9):2532-2542.

28. Kobayashi K, Hernandez LD, Galan JE, Janeway CA Jr, Medzhitov R, Flavell RA: IRAK-M is a negative regulator of Toll-like receptor signaling. Cell 2002, 110(2):191-202. 
29. Zhang G, Ghosh S: Negative regulation of toll-like receptor-mediated signaling by Tollip. J Biol Chem 2002, 277(9):7059-7065.

30. Burns K, Janssens S, Brissoni B, Olivos N, Beyaert R, Tschopp J: Inhibition of interleukin 1 receptor/Toll-like receptor signaling through the alternatively spliced, short form of MyD88 is due to its failure to recruit IRAK-4. J Exp Med 2003, 197(2):263-268.

31. Mansell A, Smith R, Doyle SL, Gray P, Fenner JE, Crack PJ, Nicholson SE, Hilton DJ, O'Neill LA, Hertzog PJ: Suppressor of cytokine signaling 1 negatively regulates Toll-like receptor signaling by mediating Mal degradation. Nat Immunol 2006, 7(2):148-155.

32. Dostert C, Petrilli V, Van Bruggen R, Steele C, Mossman BT, Tschopp J: Innate immune activation through Nalp3 inflammasome sensing of asbestos and silica. Science 2008, 320(5876):674-677.

33. Takeuchi O, Akira S: Pattern recognition receptors and inflammation. Cell 2010, 140(6):805-820.

34. Sha Q, Truong-Tran AQ, Plitt JR, Beck LA, Schleimer RP: Activation of airway epithelial cells by toll-like receptor agonists. Am J Respir Cell Mol Biol 2004, 31(3):358-364

35. Hoppstadter J, Diesel B, Zarbock R, Breinig T, Monz D, Koch M, Meyerhans A, Gortner L, Lehr CM, Huwer H, Kiemer AK: Differential cell reaction upon Toll-like receptor 4 and 9 activation in human alveolar and lung interstitial macrophages. Respir Res 2010, 11:124.

36. Maris NA, Dessing MC, de Vos AF, Bresser P, van der Zee JS, Jansen HM, Spek CA, van der Poll T: Toll-like receptor mRNA levels in alveolar macrophages after inhalation of endotoxin. Eur Respir J 2006, 28(3):622-626.

37. Andonegui G, Bonder CS, Green F, Mullaly SC, Zbytnuik L, Raharjo E, Kubes P: Endothelium-derived Toll-like receptor-4 is the key molecule in LPS-induced neutrophil sequestration into lungs. J Clin Invest 2003, 111(7):1011-1020.

38. Koller B, Kappler M, Latzin P, Gaggar A, Schreiner M, Takyar S, Kormann M, Kabesch M, Roos D, Griese M, Hartl D: TLR expression on neutrophils at the pulmonary site of infection: TLR1/TLR2-mediated up-regulation of TLR5 expression in cystic fibrosis lung disease. J Immunol 2008, 181(4):2753-2763.

39. GeurtsvanKessel CH, Lambrecht BN: Division of labor between dendritic cell subsets of the lung. Mucosal Immunol 2008, 1(6):442-450.

40. Wikstrom ME, Stumbles PA: Mouse respiratory tract dendritic cell subsets and the immunological fate of inhaled antigens. Immunol Cell Biol 2007, 85(3):182-188.

41. Plantinga $\mathrm{M}$, Hammad $\mathrm{H}$, Lambrecht BN: Origin and functional specializations of DC subsets in the lung. Eur J Immunol 2010, 40(8):2112-2118.

42. Morris GE, Whyte MK, Martin GF, Jose PJ, Dower SK, Sabroe I: Agonists of toll-like receptors 2 and 4 activate airway smooth muscle via mononuclear leukocytes. Am J Respir Crit Care Med 2005, 171(8):814-822.

43. Imai Y, Kuba K, Neely GG, Yaghubian-Malhami R, Perkmann T, van Loo G, Ermolaeva M, Veldhuizen R, Leung YH, Wang H, Liu H, Sun Y, Pasparakis M, Kopf M, Mech C, Bavari S, Peiris JS, Slutsky AS, Akira S, Hultqvist M, Holmdahl R, Nicholls J, Jiang C, Binder CJ, Penninger JM: Identification of oxidative stress and Toll-like receptor 4 signaling as a key pathway of acute lung injury. Cell 2008, 133(2):235-249.

44. Rubenfeld GD, Caldwell E, Peabody E, Weaver J, Martin DP, Neff M, Stern EJ, Hudson LD: Incidence and outcomes of acute lung injury. N Engl J Med 2005, 353(16):1685-1693.

45. Beg AA: Endogenous ligands of Toll-like receptors: implications for regulating inflammatory and immune responses. Trends Immunol 2002, 23(11):509-512.

46. Johnson GB, Brunn GJ, Kodaira Y, Platt JL: Receptor-mediated monitoring of tissue well-being via detection of soluble heparan sulfate by Toll-like receptor 4. J Immunol 2002, 168(10):5233-5239.

47. Park JS, Svetkauskaite D, He Q, Kim JY, Strassheim D, Ishizaka A, Abraham E: Involvement of toll-like receptors 2 and 4 in cellular activation by high mobility group box 1 protein. J Biol Chem 2004, 279(9):7370-7377.

48. Smiley ST, King JA, Hancock WW: Fibrinogen stimulates macrophage chemokine secretion through toll-like receptor 4. J Immunol 2001, 167(5):2887-2894.

49. Tsung A, Sahai R, Tanaka H, Nakao A, Fink MP, Lotze MT, Yang H, Li J, Tracey KJ, Geller DA, Billiar TR: The nuclear factor HMGB1 mediates hepatic injury after murine liver ischemia-reperfusion. J Exp Med 2005, 201(7):1135-1143.
50. Vabulas RM, Ahmad-Nejad P, Ghose S, Kirschning CJ, Issels RD, Wagner H: HSP70 as endogenous stimulus of the Toll/interleukin-1 receptor signal pathway. J Biol Chem 2002, 277(17):15107-15112.

51. Jiang Y, Xu J, Zhou C, Wu Z, Zhong S, Liu J, Luo W, Chen T, Qin Q, Deng P: Characterization of cytokine/chemokine profiles of severe acute respiratory syndrome. Am J Respir Crit Care Med 2005, 171(8):850-857.

52. Kaczorowski DJ, Mollen KP, Edmonds R, Billiar TR: Early events in the recognition of danger signals after tissue injury. J Leukoc Biol 2008, 83(3):546-552.

53. Rifkin IR, Leadbetter EA, Busconi L, Viglianti G, Marshak-Rothstein A: Toll-like receptors, endogenous ligands, and systemic autoimmune disease. Immunol Rev 2005, 204:27-42.

54. Taylor KR, Trowbridge JM, Rudisill JA, Termeer CC, Simon JC, Gallo RL: Hyaluronan fragments stimulate endothelial recognition of injury through TLR4. J Biol Chem 2004, 279(17):17079-17084.

55. Xiang M, Fan J: Pattern recognition receptor-dependent mechanisms of acute lung injury. Mol Med 2010, 16(1-2):69-82.

56. Yu M, Wang H, Ding A, Golenbock DT, Latz E, Czura CJ, Fenton MJ, Tracey K, Yang H: HMGB1 signals through toll-like receptor (TLR) 4 and TLR2. Shock 2006, 26(2):174-179.

57. Opitz B, van Laak V, Eitel J, Suttorp N: Innate immune recognition in infectious and noninfectious diseases of the lung. Am J Respir Crit Care Med 2010, 181(12):1294-1309.

58. Hollingsworth JW, Cook DN, Brass DM, Walker JK, Morgan DL, Foster WM, Schwartz DA: The role of Toll-like receptor 4 in environmental airway injury in mice. Am J Respir Crit Care Med 2004, 170(2):126-132.

59. Fan J, Kapus A, Li YH, Rizoli S, Marshall JC, Rotstein OD: Priming for enhanced alveolar fibrin deposition after hemorrhagic shock: role of tumor necrosis factor. Am J Respir Cell Mol Biol 2000, 22(4):412-421.

60. Fan J, Li Y, Vodovotz Y, Billiar TR, Wilson MA: Hemorrhagic shock-activated neutrophils augment TLR4 signaling-induced TLR2 upregulation in alveolar macrophages: role in hemorrhage-primed lung inflammation. Am J Physiol Lung Cell Mol Physiol 2006, 290(4):L738-L746.

61. Fan J, Marshall JC, Jimenez M, Shek PN, Zagorski J, Rotstein OD: Hemorrhagic shock primes for increased expression of cytokine-induced neutrophil chemoattractant in the lung: role in pulmonary inflammation following lipopolysaccharide. J Immunol 1998, 161(1):440-447.

62. Fan J: TLR Cross-Talk Mechanism of Hemorrhagic Shock-Primed Pulmonary Neutrophil Infiltration. Open Crit Care Med J 2010, 2:1-8.

63. Hoth JJ, Hudson WP, Brownlee NA, Yoza BK, Hiltbold EM, Meredith JW, McCall CE: Toll-like receptor 2 participates in the response to lung injury in a murine model of pulmonary contusion. Shock 2007, 28(4):447-452

64. Li Y, Xiang M, Yuan Y, Xiao G, Zhang J, Jiang Y, Vodovotz Y, Billiar TR, Wilson MA, Fan J: Hemorrhagic shock augments lung endothelial cell activation: role of temporal alterations of TLR4 and TLR2. Am J Physiol Regul Integr Comp Physiol 2009, 297(6):R1670-1680.

65. Hoth JJ, Wells JD, Brownlee NA, Hiltbold EM, Meredith JW, McCall CE, Yoza BK: Toll-like receptor 4-dependent responses to lung injury in a murine model of pulmonary contusion. Shock 2009, 31(4):376-381.

66. Buccellato LJ, Tso M, Akinci Ol, Chandel NS, Budinger GR: Reactive oxygen species are required for hyperoxia-induced Bax activation and cell death in alveolar epithelial cells. J Biol Chem 2004, 279(8):6753-6760.

67. Frank JA, Matthay MA: Science review: mechanisms of ventilator-induced injury. Crit Care 2003, 7(3):233-241.

68. Haitsma JJ, Uhlig S, Lachmann U, Verbrugge SJ, Poelma DL, Lachmann B: Exogenous surfactant reduces ventilator-induced decompartmentalization of tumor necrosis factor alpha in absence of positive end-expiratory pressure. Intensive Care Med 2002, 28(8):1131-1137.

69. Tremblay LN, Miatto D, Hamid Q, Govindarajan A, Slutsky AS: Injurious ventilation induces widespread pulmonary epithelial expression of tumor necrosis factor-alpha and interleukin-6 messenger RNA. Crit Care Med 2002, 30(8):1693-1700.

70. Vaneker M, Joosten LA, Heunks LM, Snijdelaar DG, Halbertsma FJ, van Egmond J, Netea MG, van der Hoeven JG, Scheffer GJ: Low-tidal-volume mechanical ventilation induces a toll-like receptor 4-dependent inflammatory response in healthy mice. Anesthesiology 2008, 109(3):465-472.

71. Zhang X, Shan P, Qureshi S, Homer R, Medzhitov R, Noble PW, Lee PJ: Cutting edge: TLR4 deficiency confers susceptibility to lethal oxidant lung injury. J Immunol 2005, 175(8):4834-4838. 
72. Jiang D, Liang J, Fan J, Yu S, Chen S, Luo Y, Prestwich GD, Mascarenhas MM, Garg HG, Quinn DA, Homer RJ, Goldstein DR, Bucala R, Lee PJ, Medzhitov R, Noble PW: Regulation of lung injury and repair by Toll-like receptors and hyaluronan. Nat Med 2005, 11(11):1173-1179.

73. Frerking I, Gunther A, Seeger W, Pison U: Pulmonary surfactant: functions, abnormalities and therapeutic options. Intensive Care Med 2001, 27(11):1699-1717.

74. Lewis JF, Veldhuizen RA: The future of surfactant therapy during ALI/ ARDS. Semin Respir Crit Care Med 2006, 27(4):377-388.

75. Murray LA, Knight DA, McAlonan L, Argentieri R, Joshi A, Shaheen F, Cunningham M, Alexopolou L, Flavell RA, Sarisky RT, Hogaboam CM: Deleterious role of TLR3 during hyperoxia-induced acute lung injury. Am J Respir Crit Care Med 2008, 178(12):1227-1237.

76. Burger RM, Peisach J, Horwitz SB: Activated bleomycin. A transient complex of drug, iron, and oxygen that degrades DNA. J Biol Chem 1981, 256(22):11636-11644

77. Adamson IY, Bowden DH: The pathogenesis of bloemycin-induced pulmonary fibrosis in mice. Am J Pathol 1974, 77(2):185-197.

78. Mckee CM, Penno MB, Cowman M, Burdick MD, Strieter RM, Bao C, Noble PW: Hyaluronan (HA) fragments induce chemokine gene expression in alveolar macrophages. The role of HA size and CD44. J Clin Invest 1996, 98(10):2403-2413.

79. Noble PW, McKee CM, Cowman M, Shin HS: Hyaluronan fragments activate an NF-kappa B/I-kappa B alpha autoregulatory loop in murine macrophages. J Exp Med 1996, 183(5):2373-2378.

80. Jiang D, Liang J, Li Y, Noble PW: The role of Toll-like receptors in noninfectious lung injury. Cell Res 2006, 16(8):693-701.

81. Matthay MA, Zemans RL: The Acute Respiratory Distress Syndrome: Pathogenesis and Treatment. Annu Rev Pathol 2010.

82. Looney MR: Newly recognized causes of acute lung injury: transfusion of blood products, severe acute respiratory syndrome, and avian influenza. Clin Chest Med 2006, 27(4):591-600, abstract viii.

83. Fowler RA, Lapinsky SE, Hallett D, Detsky AS, Sibbald WJ, Slutsky AS, Stewart TE: Critically ill patients with severe acute respiratory syndrome. JAMA 2003, 290(3):367-373

84. Lew TW, Kwek TK, Tai D, Earnest A, Loo S, Singh K, Kwan KM, Chan Y, Yim CF, Bek SL, Kor AC, Yap WS, Chelliah YR, Lai YC, Goh SK: Acute respiratory distress syndrome in critically ill patients with severe acute respiratory syndrome. JAMA 2003, 290(3):374-380.

85. Franks TJ, Chong PY, Chui P, Galvin JR, Lourens RM, Reid AH, Selbs E, McEvoy CP, Hayden CD, Fukuoka J, Taubenberger JK, Travis WD: Lung pathology of severe acute respiratory syndrome (SARS): a study of 8 autopsy cases from Singapore. Hum Pathol 2003, 34(8):743-748.

86. Roberts A, Lamirande EW, Vogel L, Jackson JP, Paddock CD, Guarner J, Zaki SR, Sheahan T, Baric R, Subbarao K: Animal models and vaccines for SARS-CoV infection. Virus Res 2008, 133(1):20-32.

87. Khanolkar A, Hartwig SM, Haag BA, Meyerholz DK, Harty JT, Varga SM: Tolllike receptor 4 deficiency increases disease and mortality after mouse hepatitis virus type 1 infection of susceptible C3H mice. J Virol 2009, 83(17):8946-8956.

88. Sheahan T, Morrison TE, Funkhouser W, Uematsu S, Akira S, Baric RS, Heise MT: MyD88 is required for protection from lethal infection with a mouse-adapted SARS-CoV. PLOS Pathog 2008, 4(12):e1000240.

89. Cervantes-Barragan L, Zust R, Weber F, Spiegel M, Lang KS, Akira S, Thiel V, Ludewig B: Control of coronavirus infection through plasmacytoid dendritic-cell-derived type I interferon. Blood 2007, 109(3):1131-1137.

90. Shinya K, Ebina M, Yamada S, Ono M, Kasai N, Kawaoka Y: Avian flu: influenza virus receptors in the human airway. Nature 2006, 440(7083):435-436

91. van Riel D, Munster VJ, de Wit E, Rimmelzwaan GF, Fouchier RA, Osterhaus AD, Kuiken T: H5N1 Virus Attachment to Lower Respiratory Tract. Science 2006, 312(5772):399.

92. Qiao J, Zhang M, Bi J, Wang X, Deng G, He G, Luan Z, Lv N, Xu T, Zhao L. Pulmonary fibrosis induced by H5N1 viral infection in mice. Respir Res 2009, 10(1):107.

93. Xu T, Qiao J, Zhao L, Wang G, He G, Li K, Tian Y, Gao M, Wang J, Wang H, Dong $C$ : Acute respiratory distress syndrome induced by avian influenza A (H5N1) virus in mice. Am J Respir Crit Care Med 2006, 174(9):1011-1017.

94. Lund JM, Alexopoulou L, Sato A, Karow M, Adams NC, Gale NW, Iwasaki A, Flavell RA: Recognition of single-stranded RNA viruses by Toll-like receptor 7. Proc Natl Acad Sci USA 2004, 101(15):5598-5603.
95. Koyama S, Ishii KJ, Kumar H, Tanimoto T, Coban C, Uematsu S, Kawai T, Akira S: Differential role of TLR- and RLR-signaling in the immune responses to influenza A virus infection and vaccination. J Immunol 2007, 179(7):4711-4720.

96. Heer AK, Shamshiev A, Donda A, Uematsu S, Akira S, Kopf M, Marsland BJ: TLR signaling fine-tunes anti-influenza $B$ cell responses without regulating effector T cell responses. J Immunol 2007, 178(4):2182-2191.

97. Pichlmair A, Schulz O, Tan CP, Naslund TI, Liljestrom P, Weber F, Reis e Sousa C: RIG-I-mediated antiviral responses to single-stranded RNA bearing 5'-phosphates. Science 2006, 314(5801):997-1001.

98. Weber F, Wagner V, Rasmussen SB, Hartmann R, Paludan SR: Doublestranded RNA is produced by positive-strand RNA viruses and DNA viruses but not in detectable amounts by negative-strand RNA viruses. J Virol 2006, 80(10):5059-5064.

99. Jacobs BL, Langland JO: When two strands are better than one: the mediators and modulators of the cellular responses to double-stranded RNA. Virology 1996, 219(2):339-349.

100. Marcus PI, Sekellick MJ: Defective interfering particles with covalently linked [+/-]RNA induce interferon. Nature 1977, 266(5605):815-819.

101. Guillot L, Le Goffic R, Bloch S, Escriou N, Akira S, Chignard M, Si-Tahar M: Involvement of toll-like receptor 3 in the immune response of lung epithelial cells to double-stranded RNA and influenza A virus. J BiOl Chem 2005, 280(7):5571-5580.

102. Le Goffic R, Balloy V, Lagranderie M, Alexopoulou L, Escriou N, Flavell R, Chignard M, Si-Tahar M: Detrimental contribution of the Toll-like receptor (TLR)3 to influenza A virus-induced acute pneumonia. PLOS Pathog 2006, 2(6):e53.

103. Le Goffic R, Pothlichet J, Vitour D, Fujita T, Meurs E, Chignard M, Si-Tahar M: Cutting Edge: Influenza A virus activates TLR3-dependent inflammatory and RIG-I-dependent antiviral responses in human lung epithelial cells. J Immunol 2007, 178(6):3368-3372.

104. Allen IC, Scull MA, Moore CB, Holl EK, McElvania-TeKippe E, Taxman DJ, Guthrie EH, Pickles RJ, Ting JP: The NLRP3 inflammasome mediates in vivo innate immunity to influenza $A$ virus through recognition of viral RNA. Immunity 2009, 30(4):556-565.

105. Ichinohe T, Lee HK, Ogura Y, Flavell R, Iwasaki A: Inflammasome recognition of influenza virus is essential for adaptive immune responses. J Exp Med 2009, 206(1):79-87.

106. Rehwinkel J, Tan CP, Goubau D, Schulz O, Pichlmair A, Bier K, Robb N, Vreede F, Barclay W, Fodor E, Reis e Sousa C: RIG-I detects viral genomic RNA during negative-strand RNA virus infection. Cell 2010, 140(3):397-408.

107. Sabbah A, Chang TH, Harnack R, Frohlich V, Tominaga K, Dube PH, Xiang Y, Bose S: Activation of innate immune antiviral responses by Nod2. Nat Immunol 2009, 10(10):1073-1080.

108. Thomas PG, Dash P, Aldridge JR Jr, Ellebedy AH, Reynolds C, Funk AJ, Martin WJ, Lamkanfi M, Webby RJ, Boyd KL, Doherty PC, Kanneganti TD: The intracellular sensor NLRP3 mediates key innate and healing responses to influenza $A$ virus via the regulation of caspase-1. Immunity 2009, 30(4):566-575.

109. Davis PB, Drumm M, Konstan MW: Cystic fibrosis. Am J Respir Crit Care Med 1996, 154(5):1229-1256

110. Faure K, Sawa T, Ajayi T, Fujimoto J, Moriyama K, Shime N, WienerKronish JP: TLR4 signaling is essential for survival in acute lung injury induced by virulent Pseudomonas aeruginosa secreting type III secretory toxins. Respir Res 2004, 5:1.

111. Gibson RL, Burns JL, Ramsey BW: Pathophysiology and management of pulmonary infections in cystic fibrosis. Am J Respir Crit Care Med 2003, 168(8):918-951.

112. Greene CM, Carroll TP, Smith SG, Taggart CC, Devaney J, Griffin S, O'Neill SJ, McElvaney NG: TLR-induced inflammation in cystic fibrosis and noncystic fibrosis airway epithelial cells. J Immunol 2005, 174(3):1638-1646.

113. Blohmke CJ, Victor RE, Hirschfeld AF, Elias IM, Hancock DG, Lane CR, Davidson AG, Wilcox PG, Smith KD, Overhage J, Hancock RE, Turvey SE: Innate immunity mediated by TLR5 as a novel antiinflammatory target for cystic fibrosis lung disease. J Immunol 2008, 180(11):7764-7773.

114. Morris AE, Liggitt HD, Hawn TR, Skerrett SJ: Role of Toll-like receptor 5 in the innate immune response to acute $P$. aeruginosa pneumonia. Am J Physiol Lung Cell Mol Physiol 2009, 297(6):L1112-1119.

115. Epelman S, Stack D, Bell C, Wong E, Neely GG, Krutzik S, Miyake K, Kubes $P$, Zbytnuik LD, Ma LL, Xie X, Woods DE, Mody CH: Different domains of 
Pseudomonas aeruginosa exoenzyme $\mathrm{S}$ activate distinct TLRs. J Immunol 2004, 173(3):2031-2040.

116. Hajjar AM, Ernst RK, Tsai JH, Wilson CB, Miller SI: Human Toll-like receptor 4 recognizes host-specific LPS modifications. Nat Immunol 2002, 3(4):354-359.

117. Zhang Z, Louboutin JP, Weiner DJ, Goldberg JB, Wilson JM: Human airway epithelial cells sense Pseudomonas aeruginosa infection via recognition of flagellin by Toll-like receptor 5. Infect Immun 2005, 73(11):7151-7160.

118. Balloy V, Verma A, Kuravi S, Si-Tahar M, Chignard M, Ramphal R: The role of flagellin versus motility in acute lung disease caused by Pseudomonas aeruginosa. J Infect Dis 2007, 196(2):289-296.

119. Power MR, Marshall JS, Yamamoto M, Akira S, Lin TJ: The myeloid differentiation factor 88 is dispensable for the development of a delayed host response to Pseudomonas aeruginosa lung infection in mice. Clin Exp Immunol 2006, 146(2):323-329.

120. Power MR, Peng Y, Maydanski E, Marshall JS, Lin TJ: The development of early host response to Pseudomonas aeruginosa lung infection is critically dependent on myeloid differentiation factor 88 in mice. J Biol Chem 2004, 279(47):49315-49322.

121. Ramphal R, Balloy V, Huerre M, Si-Tahar M, Chignard M: TLRs 2 and 4 are not involved in hypersusceptibility to acute Pseudomonas aeruginosa lung infections. J Immunol 2005, 175(6):3927-3934.

122. Skerrett SJ, Liggitt HD, Hajjar AM, Wilson CB: Cutting edge: myeloid differentiation factor 88 is essential for pulmonary host defense against Pseudomonas aeruginosa but not Staphylococcus aureus. J Immunol 2004, 172(6):3377-3381.

123. Skerrett SJ, Wilson CB, Liggitt HD, Hajjar AM: Redundant Toll-like receptor signaling in the pulmonary host response to Pseudomonas aeruginosa. Am J Physiol Lung Cell Mol Physiol 2007, 292(1):L312-322.

124. Ramphal R, Balloy V, Jyot J, Verma A, Si-Tahar M, Chignard M: Control of Pseudomonas aeruginosa in the lung requires the recognition of either lipopolysaccharide or flagellin. J Immunol 2008, 181(1):586-592.

125. Raoust E, Balloy V, Garcia-Verdugo I, Touqui L, Ramphal R, Chignard M: Pseudomonas aeruginosa LPS or flagellin are sufficient to activate TLRdependent signaling in murine alveolar macrophages and airway epithelial cells. PLoS One 2009, 4(10):e7259.

126. Mahenthiralingam E, Urban TA, Goldberg JB: The multifarious, multireplicon Burkholderia cepacia complex. Nat Rev Microbiol 2005, 3(2):144-156.

127. Speert DP: Advances in Burkholderia cepacia complex. Paediatr Respir Rev 2002, 3(3):230-235

128. de C Ventura GM, Le Goffic R, Balloy V, Plotkowski MC, Chignard M, SiTahar M: TLR 5, but neither TLR2 nor TLR4, is involved in lung epithelial cell response to Burkholderia cenocepacia. FEMS Immunol Med Microbiol 2008, 54(1):37-44.

129. Urban TA, Griffith A, Torok AM, Smolkin ME, Burns JL, Goldberg JB: Contribution of Burkholderia cenocepacia flagella to infectivity and inflammation. Infect Immun 2004, 72(9):5126-5134.

130. Ventura GM, Balloy V, Ramphal R, Khun H, Huerre M, Ryffel B, Plotkowski MC, Chignard M, Si-Tahar M: Lack of MyD88 protects the immunodeficient host against fatal lung inflammation triggered by the opportunistic bacteria Burkholderia cenocepacia. J Immunol 2009, 183(1):670-676.

131. Lopez AD, Shibuya K, Rao C, Mathers CD, Hansell AL, Held LS, Schmid V, Buist S: Chronic obstructive pulmonary disease: current burden and future projections. Eur Respir J 2006, 27(2):397-412.

132. Sethi S, Mallia P, Johnston SL: New paradigms in the pathogenesis of chronic obstructive pulmonary disease II. Proc Am Thorac Soc 2009, 6(6):532-534.

133. Sethi S, Murphy TF: Infection in the pathogenesis and course of chronic obstructive pulmonary disease. N Engl J Med 2008, 359(22):2355-2365.

134. Schleimer RP: Innate immune responses and chronic obstructive pulmonary disease: "Terminator" or "Terminator 2"? Proc Am Thorac Soc 2005, 2(4):342-346, discussion 371-342.

135. Zhang X, Shan P, Jiang G, Cohn L, Lee PJ: Toll-like receptor 4 deficiency causes pulmonary emphysema. J Clin Invest 2006, 116(11):3050-3059.

136. Cosio MG, Saetta M, Agusti A: Immunologic aspects of chronic obstructive pulmonary disease. N Engl J Med 2009, 360(23):2445-2454.

137. Sopori M: Effects of cigarette smoke on the immune system. Nat Rev Immunol 2002, 2(5):372-377.
138. Doz E, Noulin N, Boichot E, Guenon I, Fick L, Le Bert M, Lagente V, Ryffel B, Schnyder B, Quesniaux VF, Couillin I: Cigarette smoke-induced pulmonary inflammation is TLR4/MyD88 and IL-1R1/MyD88 signaling dependent. J Immunol 2008, 180(2):1169-1178.

139. Maes T, Bracke KR, Vermaelen KY, Demedts IK, Joos GF, Pauwels RA, Brusselle GG: Murine TLR4 is implicated in cigarette smoke-induced pulmonary inflammation. Int Arch Allergy Immunol 2006, 141(4):354-368.

140. Guerassimov A, Hoshino Y, Takubo Y, Turcotte A, Yamamoto M, Ghezzo H, Triantafillopoulos A, Whittaker K, Hoidal JR, Cosio MG: The development of emphysema in cigarette smoke-exposed mice is strain dependent. Am J Respir Crit Care Med 2004, 170(9):974-980.

141. Droemann D, Goldmann T, Tiedje T, Zabel P, Dalhoff K, Schaaf B: Toll-like receptor 2 expression is decreased on alveolar macrophages in cigarette smokers and COPD patients. Respir Res 2005, 6:68.

142. Chen H, Cowan MJ, Hasday JD, Vogel SN, Medvedev AE: Tobacco smoking inhibits expression of proinflammatory cytokines and activation of IL-1Rassociated kinase, p38, and NF-kappaB in alveolar macrophages stimulated with TLR2 and TLR4 agonists. J Immunol 2007, 179(9):6097-6106.

143. MacRedmond RE, Greene CM, Dorscheid DR, McElvaney NG, O'Neill SJ: Epithelial expression of TLR4 is modulated in COPD and by steroids, salmeterol and cigarette smoke. Respir Res 2007, 8:84.

144. Kang MJ, Lee CG, Lee JY, Dela Cruz CS, Chen ZJ, Enelow R, Elias JA: Cigarette smoke selectively enhances viral PAMP- and virus-induced pulmonary innate immune and remodeling responses in mice. $J$ Clin Invest 2008, 118(8):2771-2784.

145. Robbins CS, Bauer CM, Vujicic N, Gaschler GJ, Lichty BD, Brown EG, Stampfli MR: Cigarette smoke impacts immune inflammatory responses to influenza in mice. Am J Respir Crit Care Med 2006, 174(12):1342-1351.

146. Taylor AE, Finney-Hayward TK, Quint JK, Thomas CM, Tudhope SJ, Wedzicha JA, Barnes PJ, Donnelly LE: Defective macrophage phagocytosis of bacteria in COPD. Eur Respir J 2010, 35(5):1039-1047.

147. Berenson CS, Wrona CT, Grove LJ, Maloney J, Garlipp MA, Wallace PK, Stewart CC, Sethi S: Impaired alveolar macrophage response to Haemophilus antigens in chronic obstructive lung disease. Am J Respir Crit Care Med 2006, 174(1):31-40.

148. Bogaert D, van der Valk P, Ramdin R, Sluijter M, Monninkhof E, Hendrix R, de Groot R, Hermans PW: Host-pathogen interaction during pneumococcal infection in patients with chronic obstructive pulmonary disease. Infect Immun 2004, 72(2):818-823.

149. Groenewegen $\mathrm{KH}$, Wouters $\mathrm{EF}$ : Bacterial infections in patients requiring admission for an acute exacerbation of COPD; a 1-year prospective study. Respir Med 2003, 97(7):770-777.

150. Ko FW, Ip M, Chan PK, Chan MC, To KW, Ng SS, Chau SS, Tang JW, Hui DS: Viral etiology of acute exacerbations of COPD in Hong Kong. Chest 2007, 132(3):900-908.

151. Nseir S, Cavestri B, Di Pompeo C, Diarra M, Brisson H, Lemyze M, RousselDelvallez $M$, Durocher A: Factors predicting bacterial involvement in severe acute exacerbations of chronic obstructive pulmonary disease. Respiration 2008, 76(3):253-260.

152. Sethi S, Evans N, Grant BJ, Murphy TF: New strains of bacteria and exacerbations of chronic obstructive pulmonary disease. N Engl I Med 2002, 347(7):465-471.

153. Berry AM, Alexander JE, Mitchell TJ, Andrew PW, Hansman D, Paton JC: Effect of defined point mutations in the pneumolysin gene on the virulence of Streptococcus pneumoniae. Infect Immun 1995, 63(5):1969-1974.

154. Berry AM, Lock RA, Hansman D, Paton JC: Contribution of autolysin to virulence of Streptococcus pneumoniae. Infect Immun 1989, 57(8):2324-2330.

155. Braun JS, Novak R, Gao G, Murray PJ, Shenep JL: Pneumolysin, a protein toxin of Streptococcus pneumoniae, induces nitric oxide production from macrophages. Infect Immun 1999, 67(8):3750-3756.

156. Cockeran R, Durandt C, Feldman C, Mitchell TJ, Anderson R: Pneumolysin activates the synthesis and release of interleukin- 8 by human neutrophils in vitro. J Infect Dis 2002, 186(4):562-565.

157. Houldsworth S, Andrew PW, Mitchell TJ: Pneumolysin stimulates production of tumor necrosis factor alpha and interleukin-1 beta by human mononuclear phagocytes. Infect Immun 1994, 62(4):1501-1503.

158. Malley R, Henneke P, Morse SC, Cieslewicz MJ, Lipsitch M, Thompson CM, Kurt-Jones E, Paton JC, Wessels MR, Golenbock DT: Recognition of 
pneumolysin by Toll-like receptor 4 confers resistance to pneumococcal infection. Proc Natl Acad Sci USA 2003, 100(4):1966-1971.

159. Srivastava A, Henneke P, Visintin A, Morse SC, Martin V, Watkins C, Paton JC, Wessels MR, Golenbock DT, Malley R: The apoptotic response to pneumolysin is Toll-like receptor 4 dependent and protects against pneumococcal disease. Infect Immun 2005, 73(10):6479-6487.

160. Branger J, Knapp S, Weijer S, Leemans JC, Pater JM, Speelman P, Florquin S, van der Poll T: Role of Toll-like receptor 4 in gram-positive and gramnegative pneumonia in mice. Infect Immun 2004, 72(2):788-794.

161. Schwandner R, Dziarski R, Wesche H, Rothe M, Kirschning CJ: Peptidoglycan- and lipoteichoic acid-induced cell activation is mediated by toll-like receptor 2. J Biol Chem 1999, 274(25):17406-17409.

162. Yoshimura A, Lien E, Ingalls RR, Tuomanen E, Dziarski R, Golenbock D: Cutting edge: recognition of Gram-positive bacterial cell wall components by the innate immune system occurs via Toll-like receptor 2. J Immunol 1999, 163(1):1-5.

163. Knapp S, Wieland CW, van't Veer C, Takeuchi O, Akira S, Florquin S, van der Poll T: Toll-like receptor 2 plays a role in the early inflammatory response to murine pneumococcal pneumonia but does not contribute to antibacterial defense. J Immunol 2004, 172(5):3132-3138.

164. Albiger B, Dahlberg S, Sandgren A, Wartha F, Beiter K, Katsuragi H, Akira S, Normark $S$, Henriques-Normark B: Toll-like receptor 9 acts at an early stage in host defence against pneumococcal infection. Cell Microbiol 2007, 9(3):633-644

165. Albiger B, Sandgren A, Katsuragi H, Meyer-Hoffert U, Beiter K, Wartha F, Hornef M, Normark S, Normark BH: Myeloid differentiation factor 88dependent signalling controls bacterial growth during colonization and systemic pneumococcal disease in mice. Cell Microbiol 2005, 7(11):1603-1615.

166. Khan $A Q$, Chen Q, Wu ZQ, Paton JC, Snapper CM: Both innate immunity and type 1 humoral immunity to Streptococcus pneumoniae are mediated by MyD88 but differ in their relative levels of dependence on toll-like receptor 2. Infect Immun 2005, 73(1):298-307.

167. Xu F, Droemann D, Rupp J, Shen H, Wu X, Goldmann T, Hippenstiel S, Zabel P, Dalhoff K: Modulation of the inflammatory response to Streptococcus pneumoniae in a model of acute lung tissue infection. Am J Respir Cell Mol Biol 2008, 39(5):522-529.

168. Sapey E, Stockley RA: COPD exacerbations. 2: aetiology. Thorax 2006, 61(3):250-258.

169. Bandi V, Apicella MA, Mason E, Murphy TF, Siddiqi A, Atmar RL, Greenberg SB: Nontypeable Haemophilus influenzae in the lower respiratory tract of patients with chronic bronchitis. Am J Respir Crit Care Med 2001, 164(11):2114-2119.

170. Rao VK, Krasan GP, Hendrixson DR, Dawid S, St Geme JW: Molecular determinants of the pathogenesis of disease due to non-typable Haemophilus influenzae. FEMS Microbiol Rev 1999, 23(2):99-129.

171. Turk DC: The pathogenicity of Haemophilus influenzae. J Med Microbiol 1984, 18(1):1-16

172. Wieland CW, Florquin S, Maris NA, Hoebe K, Beutler B, Takeda K, Akira S, van der Poll T: The MyD88-dependent, but not the MyD88-independent, pathway of TLR4 signaling is important in clearing nontypeable haemophilus influenzae from the mouse lung. J Immunol 2005, 175(9):6042-6049.

173. Teng F, Slavik V, Duffy KE, San Mateo L, Goldschmidt R: Toll-like receptor 3 is involved in airway epithelial cell response to nontypeable Haemophilus influenzae. Cell Immunol 2010, 260(2):98-104.

174. Renz H, Bradley K, Gelfand EW: Production of interleukin-4 and interferongamma by TCR-V beta-expressing T-cell subsets in allergen-sensitized mice. Am J Respir Cell Mol Biol 1996, 14(1):36-43.

175. Robinson D, Hamid Q, Bentley A, Ying S, Kay AB, Durham SR: Activation of CD4+ T cells, increased TH2-type cytokine mRNA expression, and eosinophil recruitment in bronchoalveolar lavage after allergen inhalation challenge in patients with atopic asthma. J Allergy Clin Immunol 1993, 92(2):313-324.

176. Tulic MK, Hurrelbrink RJ, Prele CM, Laing IA, Upham JW, Le Souef P, Sly PD, Holt PG: TLR4 polymorphisms mediate impaired responses to respiratory syncytial virus and lipopolysaccharide. J Immunol 2007, 179(1):132-140.

177. Chaudhuri N, Dower SK, Whyte MK, Sabroe I: Toll-like receptors and chronic lung disease. Clin Sci (Lond) 2005, 109(2):125-133.

178. Eisenbarth SC, Piggott DA, Huleatt JW, Visintin I, Herrick CA, Bottomly K: Lipopolysaccharide-enhanced, toll-like receptor 4-dependent $\mathrm{T}$ helper cell type 2 responses to inhaled antigen. J Exp Med 2002, 196(12):1645-1651.

179. Erb KJ, Holloway JW, Sobeck A, Moll H, Le Gros G: Infection of mice with Mycobacterium bovis-Bacillus Calmette-Guerin (BCG) suppresses allergen-induced airway eosinophilia. J Exp Med 1998, 187(4):561-569.

180. Broide D, Schwarze J, Tighe H, Gifford T, Nguyen MD, Malek S, Van Uden J, Martin-Orozco E, Gelfand EW, Raz E: Immunostimulatory DNA sequences inhibit IL-5, eosinophilic inflammation, and airway hyperresponsiveness in mice. J Immunol 1998, 161(12):7054-7062.

181. Kline JN, Waldschmidt TJ, Businga TR, Lemish JE, Weinstock JV, Thorne PS, Krieg AM: Modulation of airway inflammation by CpG oligodeoxynucleotides in a murine model of asthma. J Immunol 1998, 160(6):2555-2559.

182. Conrad ML, Ferstl R, Teich R, Brand S, Blumer N, Yildirim AO, Patrascan CC, Hanuszkiewicz A, Akira S, Wagner H, Holst O, von Mutius E, Pfefferle PI, Kirschning $\mathrm{CJ}$, Garn H, Renz H: Maternal TLR signaling is required for prenatal asthma protection by the nonpathogenic microbe Acinetobacter Iwoffii F78. J Exp Med 2009, 206(13):2869-2877.

183. Hammad H, Chieppa M, Perros F, Willart MA, Germain RN, Lambrecht BN: House dust mite allergen induces asthma via Toll-like receptor 4 triggering of airway structural cells. Nat Med 2009, 15(4):410-416

184. Yang D, Chen Q, Su SB, Zhang P, Kurosaka K, Caspi RR, Michalek SM, Rosenberg HF, Zhang N, Oppenheim JJ: Eosinophil-derived neurotoxin acts as an alarmin to activate the TLR2-MyD88 signal pathway in dendritic cells and enhances Th2 immune responses. J Exp Med 2008, 205(1):79-90

185. Sokol CL, Chu NQ, Yu S, Nish SA, Laufer TM, Medzhitov R: Basophils function as antigen-presenting cells for an allergen-induced Thelper type 2 response. Nat Immunol 2009, 10(7):713-720.

186. Moller-Larsen S, Nyegaard M, Haagerup A, Vestbo J, Kruse TA, Borglum AD: Association analysis identifies TLR7 and TLR8 as novel risk genes in asthma and related disorders. Thorax 2008, 63(12):1064-1069.

187. Camateros P, Tamaoka M, Hassan M, Marino R, Moisan J, Marion D, Guiot MC, Martin JG, Radzioch D: Chronic asthma-induced airway remodeling is prevented by toll-like receptor-7/8 ligand S28463. Am J Respir Crit Care Med 2007, 175(12):1241-1249.

188. Moisan J, Camateros $P$, Thuraisingam T, Marion D, Koohsari H, Martin $P$, Boghdady ML, Ding A, Gaestel M, Guiot MC, Martin JG, Radzioch D: TLR7 ligand prevents allergen-induced airway hyperresponsiveness and eosinophilia in allergic asthma by a MYD88-dependent and MK2independent pathway. Am J Physiol Lung Cell Mol Physiol 2006, 290(5): L987-995.

189. Lazarus R, Raby BA, Lange C, Silverman EK, Kwiatkowski DJ, Vercelli D, Klimecki WJ, Martinez FD, Weiss ST: TOLL-like receptor 10 genetic variation is associated with asthma in two independent samples. Am 」 Respir Crit Care Med 2004, 170(6):594-600.

190. Genuneit J, Cantelmo JL, Weinmayr G, Wong GW, Cooper PJ, Riikjarv MA, Gotua M, Kabesch M, von Mutius E, Forastiere F, Crane J, Nystad W, ElSharif N, Batlles-Garrido J, Garcia-Marcos L, Garcia-Hernandez G, MoralesSuarez-Varela M, Nilsson L, Braback L, Saraclar Y, Weiland SK, Cookson WO, Strachan D, Moffatt MF: A multi-centre study of candidate genes for wheeze and allergy: the International Study of Asthma and Allergies in Childhood Phase 2. Clin Exp Allergy 2009, 39(12):1875-1888.

191. Kline JN, Krieg AM: Toll-like receptor 9 activation with CpG oligodeoxynucleotides for asthma therapy. Drug News Perspect 2008, 21(8):434-439.

192. Pelaia G, Vatrella A, Gallelli L, Renda T, Cazzola M, Maselli R, Marsico SA: Respiratory infections and asthma. Respir Med 2006, 100(5):775-784.

193. Allegra L, Blasi F, Centanni S, Cosentini R, Denti F, Raccanelli R, Tarsia P, Valenti V: Acute exacerbations of asthma in adults: role of Chlamydia pneumoniae infection. Eur Respir J 1994, 7(12):2165-2168.

194. Biscardi S, Lorrot M, Marc E, Moulin F, Boutonnat-Faucher B, Heilbronner C, Iniguez JL, Chaussain M, Nicand E, Raymond J, Gendrel D: Mycoplasma pneumoniae and asthma in children. Clin Infect Dis 2004, 38(10):1341-1346.

195. Naiki Y, Michelsen KS, Schroder NW, Alsabeh R, Slepenkin A, Zhang W, Chen S, Wei B, Bulut $Y$, Wong MH, Peterson EM, Arditi M: MyD88 is pivotal for the early inflammatory response and subsequent bacterial clearance and survival in a mouse model of Chlamydia pneumoniae pneumonia. $J$ Biol Chem 2005, 280(32):29242-29249. 
196. Rodriguez N, Wantia N, Fend F, Durr S, Wagner H, Miethke T: Differential involvement of TLR2 and TLR4 in host survival during pulmonary infection with Chlamydia pneumoniae. Eur J Immunol 2006, 36(5):1145-1155.

197. Chu HW, Jeyaseelan S, Rino JG, Voelker DR, Wexler RB, Campbell K, Harbeck RJ, Martin RJ: TLR2 signaling is critical for Mycoplasma pneumoniae-induced airway mucin expression. J Immunol 2005, 174(9):5713-5719.

198. Kraft M, Adler KB, Ingram JL, Crews AL, Atkinson TP, Cairns CB, Krause DC, Chu HW: Mycoplasma pneumoniae induces airway epithelial cell expression of MUC5AC in asthma. Eur Respir J 2008, 31(1):43-46.

199. Wu Q, Martin RJ, Lafasto S, Efaw BJ, Rino JG, Harbeck RJ, Chu HW: Toll-like receptor 2 down-regulation in established mouse allergic lungs contributes to decreased mycoplasma clearance. Am J Respir Crit Care Med 2008, 177(7):720-729.

200. Andersen P: Pathogenesis of lower respiratory tract infections due to Chlamydia, Mycoplasma, Legionella and viruses. Thorax 1998, 53(4):302-307.

201. Kraft M, Cassell GH, Pak J, Martin RJ: Mycoplasma pneumoniae and Chlamydia pneumoniae in asthma: effect of clarithromycin. Chest 2002, 121(6):1782-1788.

202. Piedimonte $\mathrm{G}$ : The association between respiratory syncytial virus infection and reactive airway disease. Respir Med 2002, 96(Suppl B): S25-29.

203. Tan WC: Viruses in asthma exacerbations. Curr Opin Pulm Med 2005, 11(1):21-26.

204. Hall CB: Respiratory syncytial virus and parainfluenza virus. N Engl J Med 2001, 344(25):1917-1928.

205. Haynes LM, Moore DD, Kurt-Jones EA, Finberg RW, Anderson LJ, Tripp RA: Involvement of toll-like receptor 4 in innate immunity to respiratory syncytial virus. J Virol 2001, 75(22):10730-10737.

206. Thompson WW, Shay DK, Weintraub E, Brammer L, Cox N, Anderson LJ, Fukuda $\mathrm{K}$ : Mortality associated with influenza and respiratory syncytial virus in the United States. JAMA 2003, 289(2):179-186.

207. Bont L, Heijnen CJ, Kavelaars A, van Aalderen WM, Brus F, Draaisma JT, Geelen SM, Kimpen JL: Monocyte IL-10 production during respiratory syncytial virus bronchiolitis is associated with recurrent wheezing in a one-year follow-up study. Am J Respir Crit Care Med 2000, 161(5):1518-1523.

208. Ehlenfield DR, Cameron K, Welliver RC: Eosinophilia at the time of respiratory syncytial virus bronchiolitis predicts childhood reactive airway disease. Pediatrics 2000, 105(1 Pt 1):79-83.

209. Renzi PM, Turgeon JP, Yang JP, Drblik SP, Marcotte JE, Pedneault L, Spier S: Cellular immunity is activated and a $\mathrm{TH}-2$ response is associated with early wheezing in infants after bronchiolitis. J Pediatr 1997, 130(4):584-593.

210. Roman M, Calhoun WJ, Hinton KL, Avendano LF, Simon V, Escobar AM, Gaggero A, Diaz PV: Respiratory syncytial virus infection in infants is associated with predominant Th-2-like response. Am J Respir Crit Care Med 1997, 156(1):190-195.

211. Sigurs N: A cohort of children hospitalised with acute RSV bronchiolitis: impact on later respiratory disease. Paediatr Respir Rev 2002, 3(3):177-183.

212. Meyer G, Deplanche M, Schelcher F: Human and bovine respiratory syncytial virus vaccine research and development. Comp Immunol Microbiol Infect Dis 2008, 31(2-3):191-225.

213. Xie XH, Law HK, Wang LJ, Li X, Yang XQ, Liu EM: Lipopolysaccharide induces IL- 6 production in respiratory syncytial virus-infected airway epithelial cells through the toll-like receptor 4 signaling pathway. Pediatr Res 2009, 65(2):156-162.

214. Kurt-Jones EA, Popova L, Kwinn L, Haynes LM, Jones LP, Tripp RA, Walsh EE, Freeman MW, Golenbock DT, Anderson L, Finberg RW: Pattern recognition receptors TLR4 and CD14 mediate response to respiratory syncytial virus. Nat Immunol 2000, 1(5):398-401.

215. Haeberle HA, Takizawa R, Casola A, Brasier AR, Dieterich HJ, Van Rooijen N, Gatalica Z, Garofalo RP: Respiratory syncytial virus-induced activation of nuclear factor-kappaB in the lung involves alveolar macrophages and toll-like receptor 4-dependent pathways. J Infect Dis 2002, 186(9):1199-1206.

216. Awomoyi AA, Rallabhandi P, Pollin TI, Lorenz E, Sztein MB, Boukhvalova MS, Hemming VG, Blanco JC, Vogel SN: Association of TLR4 polymorphisms with symptomatic respiratory syncytial virus infection in high-risk infants and young children. J Immunol 2007, 179(5):3171-3177.

217. Murawski MR, Bowen GN, Cerny AM, Anderson LJ, Haynes LM, Tripp RA, Kurt-Jones EA, Finberg RW: Respiratory syncytial virus activates innate immunity through Toll-like receptor 2. J Virol 2009, 83(3):1492-1500.

218. Rudd BD, Burstein E, Duckett CS, Li X, Lukacs NW: Differential role for TLR3 in respiratory syncytial virus-induced chemokine expression. J Virol 2005, 79(6):3350-3357.

219. Rudd BD, Smit JJ, Flavell RA, Alexopoulou L, Schaller MA, Gruber A, Berlin AA, Lukacs NW: Deletion of TLR3 alters the pulmonary immune environment and mucus production during respiratory syncytial virus infection. J Immunol 2006, 176(3):1937-1942.

220. Liu P, Jamaluddin M, Li K, Garofalo RP, Casola A, Brasier AR: Retinoic acidinducible gene I mediates early antiviral response and Toll-like receptor 3 expression in respiratory syncytial virus-infected airway epithelial cells. J Virol 2007, 81(3):1401-1411.

doi:10.1186/1476-9255-7-57

Cite this article as: Lafferty et al:: The role of toll-like receptors in acute and chronic lung inflammation. Journal of Inflammation 2010 7:57.

\section{Submit your next manuscript to BioMed Central and take full advantage of:}

- Convenient online submission

- Thorough peer review

- No space constraints or color figure charges

- Immediate publication on acceptance

- Inclusion in PubMed, CAS, Scopus and Google Scholar

- Research which is freely available for redistribution

Submit your manuscript at www.biomedcentral.com/submit
Biomed Central 